FESIEE

Fundación Emilio Soldevilla para la Investigación y Desarrolto de la Economia de la Empresa

\section{Management Letters / Cuadernos de Gestión}

\author{
journal homepage: http://www.ehu.eus/cuadernosdegestion/revista/es/
}

ISSN: 1131-6837 / e-ISSN: 1988-2157

\title{
The Circular Economy and Sustainability: A Systematic Literature Review
}

\section{La economía circular y la sostenibilidad: una revisión sistemática de la literatura}

\author{
Mercedes Gil-Lamata ${ }^{\star}$, M. ${ }^{a}$ Pilar Latorre-Martínez ${ }^{\mathrm{a}}$ \\ ${ }^{a}$ Department of Business and Administration, Facultad de Ciencias Sociales y del Trabajo, Violante de Hungría, 23, 50009, Zaragoza, Spain. - latorrep@unizar.es - \\ https://orcid.org/0000-0002-8486-6885
}

* Corresponding author: Department of Business and Administration, Facultad de Economía y Empresa, University of Zaragoza, Gran Vía 2, 50005, Zaragoza, Spain. - mercedesgil@unizar.es - https://orcid.org/0000-0002-1816-5394

\section{A R T I C L E I N F O}

Received 10 May 2021,

Accepted 04 October 2021

Available online 10 February 2022

DOI: $10.5295 / \mathrm{cdg} .211492 \mathrm{mg}$

JEL: Q56, M11

\section{A B S T R A C T}

The interest of this study lies in the fact that the transition from a linear to a circular economy is of key interest in relevant business and academic fields, although the circular economy is an emerging issue and theoretical and empirical research has been limited until recently. However, circular business models are receiving more and more attention, and it is therefore strategically necessary to develop tools that facilitate their implementation. Therefore, because of increasing interest amongst research in the circular economy and sustainability, the purpose of the present study and its strength lies in the systematic presentation of both of these specific academic streams. The approach was qualitative and based on a systematic literature review. We examined several areas in which the circular economy has a place. We highlight sustainability, consumer behaviour, innovation, remanufacturing, operations management, supply chains, intellectual capital, 3D printing, big data, and recycling. We also consider drivers, challenges, the relationship between circular economy and small to medium-sized enterprises, and the influence of circular economy in specific sectors such as textiles and food. It is hoped that the study will facilitate a possible sustainable solution that contrasts with the current linear model of production and resource management. The circular economy has the potential to create positive synergies in economic, social, and environmental areas, despite its recent origin.

Keywords: Circular Economy, Sustainability, Environment, Management, Systematic Review.

\section{R E S U M E N}

El interés del presente estudio radica en que la transición de una economía lineal a una circular tiene gran influencia tanto en los ámbitos empresariales como en los académicos, aunque la economía circular es un tema emergente y la investigación teórica y empírica ha sido limitada hasta hace poco. Si bien, los modelos empresariales circulares están recibiendo cada vez más atención, por lo que es estratégicamente necesario desarrollar herramientas que faciliten su aplicación. Por ello, debido al creciente interés de la investigación hacia la economía circular en términos de sostenibilidad, el objetivo del presente estudio y su principal fortaleza reside en la presentación sistemática de estas dos corrientes académicas específicas. El enfoque aplicado fue cualitativo y se basó en una revisión sistemática de la literatura. Estudiamos varias áreas en las que la economía circular tiene cabida. Entre ellas destacamos la sostenibilidad, el comportamiento de los consumidores, la innovación, la remanufacturación, la gestión de operaciones, las cadenas de suministro, el capital intelectual, la impresión 3D, el big data y el reciclaje. También consideramos los impulsores y los retos, existentes entre la economía circular y las pequeñas y medianas empresas, así como la influencia de la economía circular en sectores específicos como el textil y el alimentario. Se espera que este estudio proporcione una visión sostenible que contrasta con el actual modelo lineal de producción y gestión de recursos; ya que la economía circular tiene el potencial de crear sinergias positivas en los ámbitos económico, social y medioambiental, a pesar de su reciente origen.

Palabras clave: Economía Circular, Sostenibilidad, Medio Ambiente, Gestión, Revisión Sistemática. 


\section{INTRODUCTION}

The reason that justifies the need for the circular economy (CE) lies in the increase in the world population and the manufacture of consumer goods that are summarily discarded, probably because of the rapid and dynamic technological change. All of this is seriously affecting the environment (Allwood et al., 2011). Humanity is facing serious ecological problems - climate change, pollution, deforestation, soil degradation, species extinction and the loss of biodiversity. Immediate action must be taken to compel the sustainable use of natural resources and the recycling of waste. This will protect the planet and its resources, and the CE can play a part.

This background highlights the importance of addressing what is presently a significant research gap. It is hoped that the provision of an integrated theoretical CE framework will contribute to the United Nations Sustainable Development Goals (SDGs) for 2030. At the same time, the CE favours competitiveness and innovation, leading to desirable corporate financial returns and further economic development (United Nations, 2015). The present study recognises the importance of SDG number 12 - "responsible production and consumption"which seeks both economic growth and sustainable development. A radical change in current modes of production and consumption is needed.

The aim of the present study and its strength lies in the systematic presentation of a specific academic theme, the CE and sustainability so that it can be explored in greater depth. The study provides an overview of the topic and sets an agenda for future research.

The remainder of the study is organised as follows. Section 2 provides the background to the $\mathrm{CE}$, as well as a definition of the concept itself. Section 3 presents the study methodology, including the selection and analysis of the sample. The results are discussed in Section 4. The CE is considered in relation to a series of dimensions that have acquired great importance within the literature. Section 5 contains the most relevant conclusions and the most significant contributions of the study. Its limitations, future research directions and managerial implications also can be found in Section 5 .

\section{THE CIRCULAR ECONOMY}

\subsection{Background to the Circular Economy}

Because of the projected population increase, it is expected that the demand for raw materials will double in the next forty years (EC, 2018). The demand for energy will also increase, as there is a positive correlation between greater wealth and energy consumption (Malinauskaite et al., 2017). We are being confronted with an increase in carbon dioxide emissions, the plastics pollution of the oceans, and a rise in sea levels. For these reasons, we have begun to speak of climate refugees, namely, people who will be forcibly displaced because of climate change (Ahmed, 2018).

Several years ago, measures such as recycling were put into place to alleviate the climate emergency. In the European Union a whole, the municipal waste recycling rate was $27.3 \%$ in 2000 and $47.7 \%$ in 2019 (EC, 2021). However, these measures do not seem to be sufficient, because most waste is non-recyclable (Kirchherr et al., 2017). In addition, the exponential increase in consumption has increased the ecological footprint year on year (EMAF, 2015). It is therefore necessary that we adopt a sustainable lifestyle and replace the linear economy with the CE. Manufacturers must take responsibility for what happens to the goods they produce. The response to the climate emergency, a growing global environmental awareness, and the fact that recycling does not seem to be enough led to the emergence of the concept of the CE. However, the boundaries between the CE and sustainable development or environmental sustainability are blurred, confusing, and still subject to debate amongst scholars (Geissdoerfer et al., 2017; Ghisellini et al., 2016; Urbinati et al., 2017).

\subsection{The role of the Sustainable Development Goals in the Circular Economy}

In response to the circumstances described above, in 2015 the United Nations established 17 SDGs, to be achieved by 2030. Although each one focuses on different aspects, they are underpinned by a common idea: the implementation of the $\mathrm{CE}$ as a sustainable solution, rather than the linear model of the production and management of resources, which has had negative economic, environmental and social consequences.

This series of measures was suggested because of the potential offered by transitioning to a sustainability based CE. Cooperation on climate objectives and the conservation of environmental resources, the creation of greater wealth and the generation of competitive advantage would be possible if it were to be realised.

However, even if material recovery were to be accepted as a global objective, several institutional and financial barriers would have to be overcome (Pajunen and Heiskanen, 2012). For instance, companies will need to design their business models in accordance with the principles of a functioning CE (Centobelli et al., 2020).

\subsection{Research on the Circular Economy and Waste Management}

The CE is currently a "hot topic" amongst academics and professionals. This is demonstrated by the exponential increase in publications on the subject in high impact journals (Kirchherr et al., 2017).

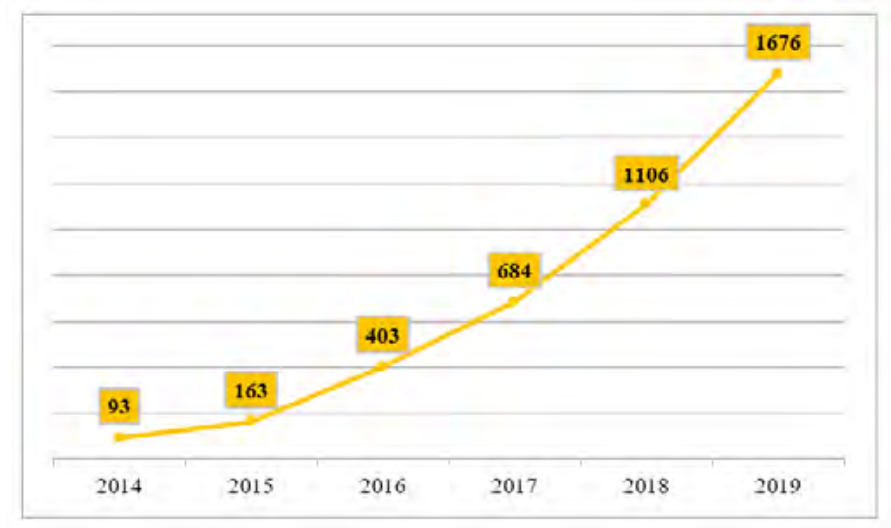

Figure 1

Articles on the CE in JCR high impact journals (2014-2019)

Source: Own elaboration from WoS. 
Figure 1 shows that over 2014-2019 there has been an exponential increase in articles on the Web of Science (WoS) in which issues related to the $\mathrm{CE}$ are addressed. Ninety-three articles were published in 2004, and the number had risen by a factor of 18 to almost 1700 by 2019. This trend is continuing through 2021, according to the data that are available.

Referring to existing definitions of CE, Kirchherr et al. (2017) carried out a comprehensive analysis of 114 definitions, and they concluded that that the concept means different things to different authors. Overall, CE is regarded as an economic system for the benefit of current and future generations, one that is capable of sustaining the life of a product through reduction and alternative reuse, followed by the recycling and recovery of materials via a range of different processes (production, distribution and consumption). In addition, this new economic system operates at different levels: at the micro level with products, consumers, and companies; at the meso level with eco-industrial parks; and at the macro level with cities, regions and countries. The objective is always the same: to achieve sustainable development, while achieving environmental quality, economic prosperity, and social equity (Kirchherr et al., 2017).

Finally, and closely linked to CE research, one of the most recurrent themes amongst academics was waste management. Figure 2 shows the preferred route to be followed in the management of waste and residues. This is based on the extent of the damage they cause the environment. The most sustainable action is the reduction in the use of materials, followed by their reuse, recycling, recovery, and finally (the alternative of last resort) is landfill (EC, 2016).

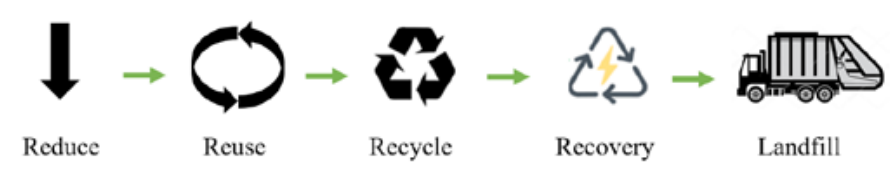

Figure 2

The waste hierarchy

Source: Own elaboration based on the Waste Framework Directive (1975/442/EEC).

As the source of the figure suggests, this schema is promoted by the European Union, by several national governments and by many companies globally (Korhonen et al., 2018). It was introduced with the intention of addressing environmental degradation and resource scarcity resulting from economic development, after a long period when industry required guidance to implement strategies for sustainable development (Murray et al., 2017).

\subsection{The economic impact of the Circular Economy}

At the microeconomic level, the application of the CE, by improving relationships with customers and reducing the environmental impact, allows the reduction of manufacturing costs amongst other economic benefits (Linder and Williander, 2017). In the same vein, various reports have also spread the word that this form of recovery increases GDP. The Ellen McArthur Foundation calculated that the $\mathrm{CE}$ will grow the European economy by 7\% (EMAF, 2015). Other studies have confirmed the positive economic impact of materials recovery and have shown that there is a positive relationship between GDP and all types of waste generation (Malinauskaite et al., 2017).

\section{METHODOLOGY}

To achieve the proposed objectives, a systematic review of the literature was carried out. This method is considered a valuable tool to provide a holistic view of existing research on a specific topic for ease of understanding (Gao et al., 2019). Thus, a rigorous scientific investigation of the current academic literature is available below. To better represent the research search process, we present Figure 3, which was developed following the PRISMA flow diagram procedures.

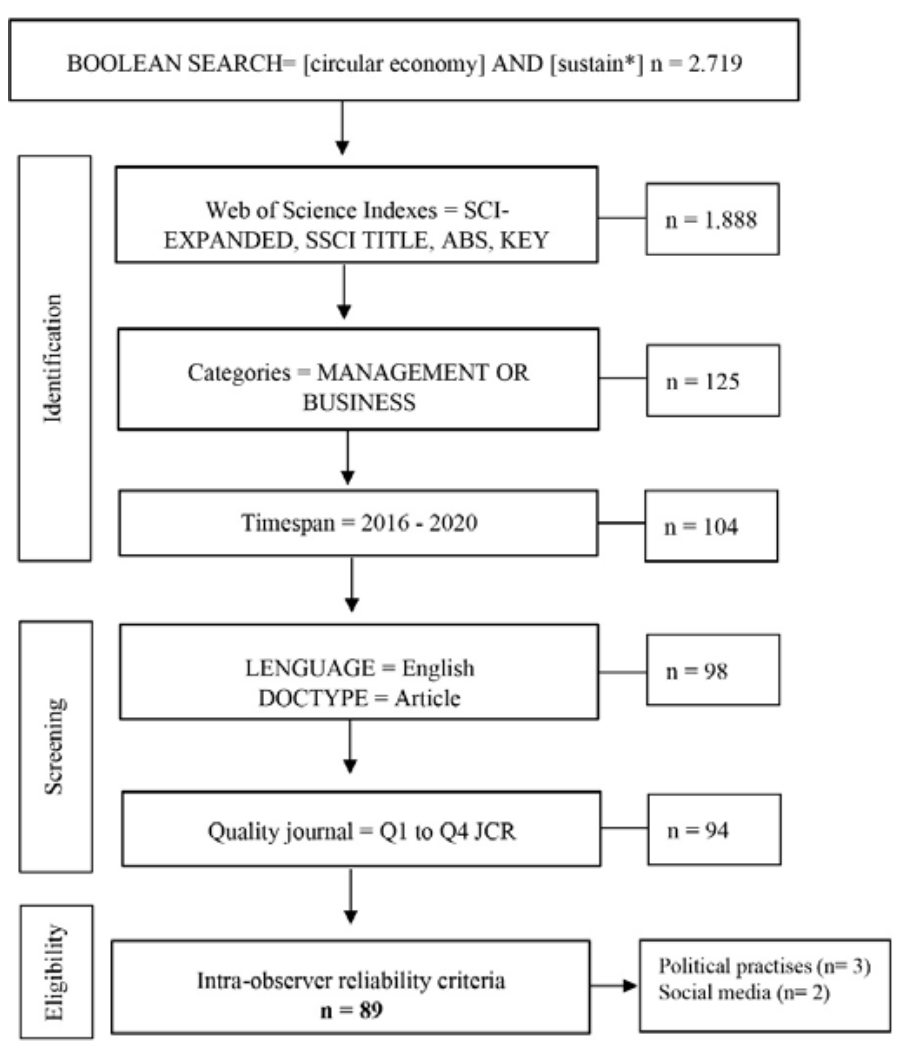

Figure 3

PRISMA diagram of the systematic literature review

Source: Own elaboration based on PRISMA.

\subsection{Sample selection, screening and eligibility}

First, the WoS was used to identify appropriate publications. This database was used because it includes the most relevant, impactful, and up-to-date peer-reviewed academic publications. The search was conducted on June, 2020.

In the search and screening processes the Boolean search was performed on the titles, abstracts and keywords. The categories selected are Management and Business, and the period under analysis covers 2016 to 2020 . To further guarantee objectivity, only documents that have been published in journals were in- 
cluded, thus excluding book chapters or conference documents. We restricted our search to articles published in English. After that, we apply one quality criterion. We include articles published in journals indexed in quartiles 1 to 4 of the 2019 JCR. Therefore, the conclusions we draw will be based on high quality and impact publications.

Next, the criterion of intra-observer reliability is followed to eliminate articles that do not fit with the objectives of our search. All the abstracts were read, as well as several introductions and conclusions, to determine with greater robustness the exclusion or inclusion of the sample articles. Finally, 5 articles were removed because they do not fit the requirements. 3 focus on political recommendation and 2 use social media. 89 articles across 30 journals met the inclusion criteria. These 89 articles were read in their entirety for the final analysis and synthesis.

To quickly see which are the most used terms in the selected articles, figure 4 illustrates the most used words in papers that have been analysed. As expected, the keywords used for the Boolean search "circular" "economy" and "sustain" highlight from the rest. Are also relevant the abbreviation of circular economy (“CE"), "model”, "business", "value" and "product".

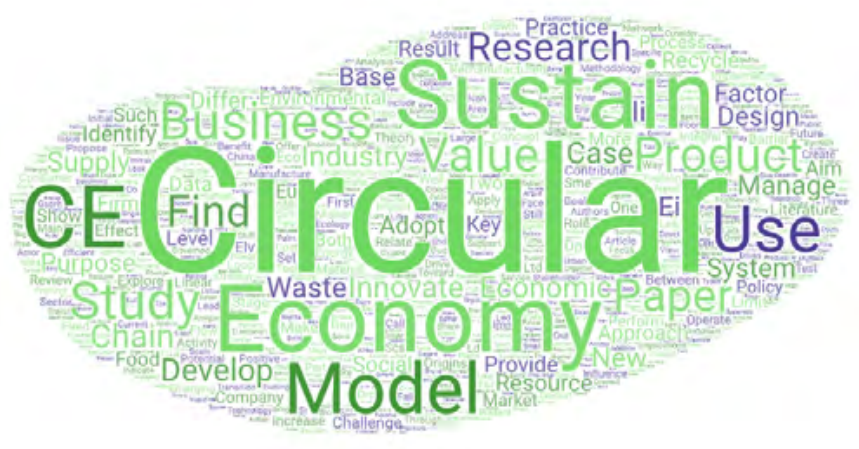

Figure 4

Word cloud produced from the paper's abstracts

Source: Own elaboration generated through WordArt.

\subsection{Sample description}

The evolution, perspectives and contribution of the articles were examined. These would later be subject to more detailed analysis. The journals in which the articles appeared were identified, as was their impact, so that their relative quality could be assessed. The way the articles were divided across the journals was examined. For this purpose, we used the quartiles of the journals, and we considered the following aspects: the journal's indicator impact (JCR is used); the year of publication; the research method adopted (quantitative or qualitative); and the scope in terms of geography and activity.

Table 1 shows the distribution of the 89 articles amongst the journals in which they were published. The journals are listed in descending order according to the number of articles published in each. The journal with the greatest number of published articles was Business Strategy and the Environment, with a total of 23. The next was Management Decision, with nine articles. The Amfiteatru Economic and the California Management Review occupied leading positions. The table shows the variety of journals that have expressed an interest in the topics, with up to 30 indexed publications in the fields of management and business publishing studies on the CE. However, only 13 appear in the table, as the remaining 17 are grouped in the same block because they all have only one article.

Table 1

Distribution of articles according to the journal of publication (2016-2020)

\begin{tabular}{lc}
\hline \multicolumn{1}{c}{ Journal } & $\begin{array}{c}\text { No. of } \\
\text { articles }\end{array}$ \\
\hline 1. Business Strategy and the Environment & 23 \\
2. Management Decision & 9 \\
3. Amfiteatru Economic & 7 \\
4. California Management Review & 6 \\
5. Corporate Social Responsibility and Environmental & 4 \\
$\quad$ Management & \\
6. Journal of Fashion Marketing and Management & 4 \\
7. Journal of Manufacturing Technology Management & 4 \\
8. Technological Forecasting and Social Change & 4 \\
9. Culture and Organization & 3 \\
10. Supply Chain Management: An International Journal & 2 \\
11. International Journal of Logistics Management & 2 \\
12. Journal of Enterprise Information Management & 2 \\
13. Omega: The International Journal of Management & 2 \\
Science & \\
\hline
\end{tabular}

Group (1)

Source: Own elaboration from WoS.

Group (1) = journals that have published an article during the time period under review (Business History, Business Horizons, International Entrepreneurship and Management Journal, International Journal of Contemporaty Hospitality Management, International Journal of Physical Distribution \& Logistics Management, International Journal of Operations and Production Management, Journal of Business Economics and Management, Journal of Business Ethics, Journal of Business Research, Journal of Macromarketing, Journal of Operations Management, M\&SOM-Manufacturing \& Service Operations Management, Research Policy, Scandinavian Journal of Management, Socio-Economic Planning Sciences, Systems Research and Behavioral Science, Total Quality Management \& Business Excellence).

To quantify the dispersion of the publications, a Herfindahl-type index was calculated. This produced a value of 0.101 . When we consider that this indicator is limited to between 0 and 1 , where a value of one indicates maximum concentration and values close to zero indicate a high dispersion, the value obtained confirms the wide range of destinations at which research relating to the CE has already arrived.

Another way to observe how the sample journals are distributed the articles and which are the most important journals in terms of the number of articles published on EC and sustainability, a hierarchical chart is made, where you can also see in black highlighted the magazines that are in the Q1 quartile of the JCR category. 


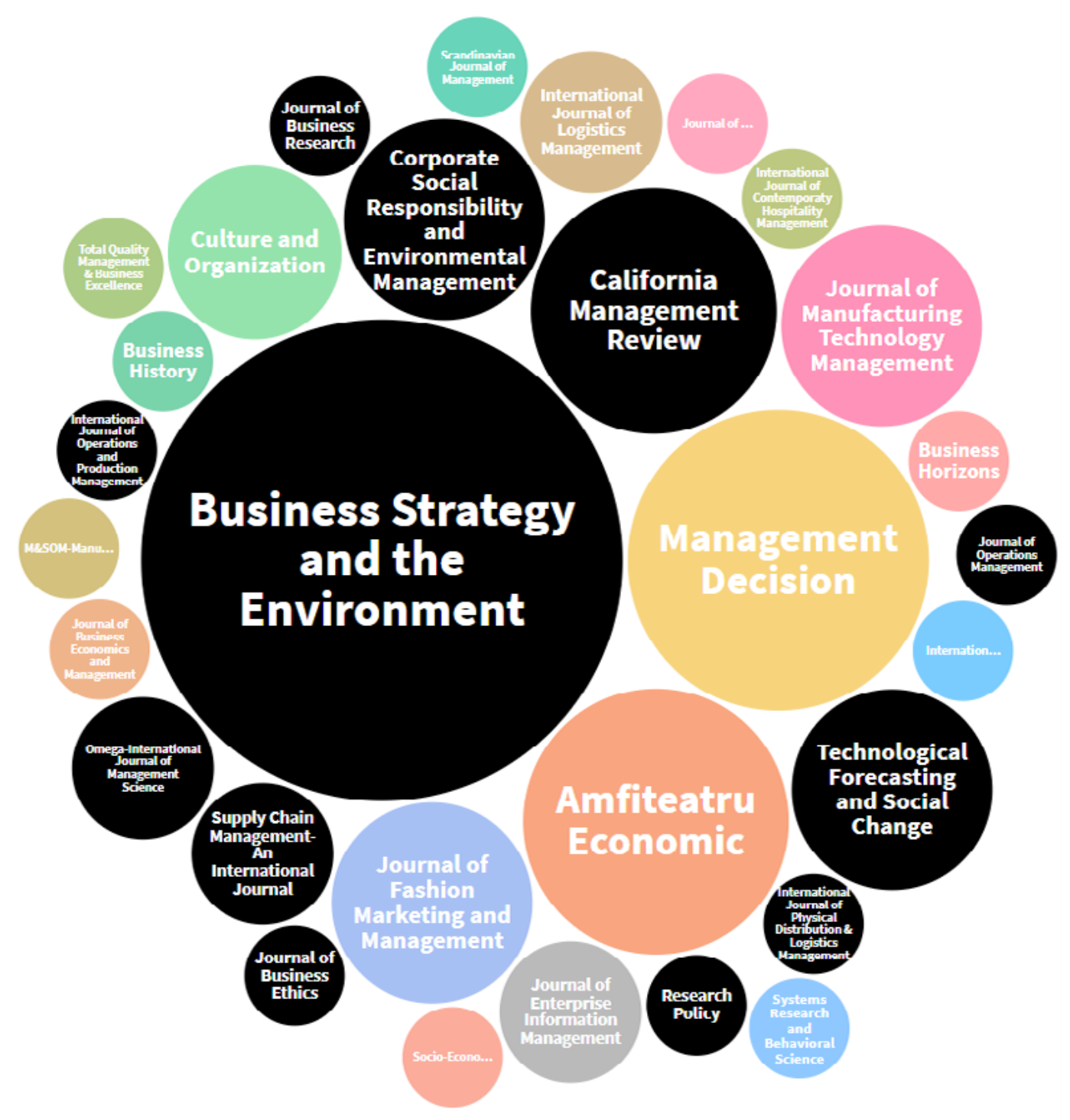

Figure 5

Sample journals selected according to the number of articles Source: Own elaboration.

A larger circle size indicates a greater number of published articles on EC and sustainability. Thus, the Q1 magazines of the most recurrent Business \& Management categories in this topic would be Business Strategy and the Environment with 23 articles published, California Management Review with 6 articles published and Corporate Social Responsibility and Environmental Management with 4 articles.

Figure 6 shows the proportion of sample articles in JCR categories according to the quartile of the journal of publication. Of those chosen, 53.93\% were in Q1.

Most of the studies applied qualitative methods (80.89\%). Quantitative studies represented only $16.85 \%$ of the total sample, so there is a need for expansion in this area. Mixed method approaches were also lacking. Figure 7 illustrates these results.

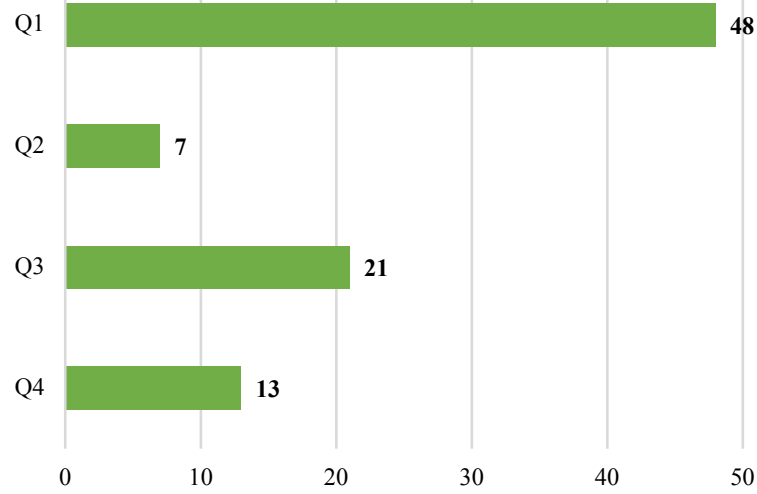

Figure 6

Journal impact indicator Source: Own elaboration from WoS. 


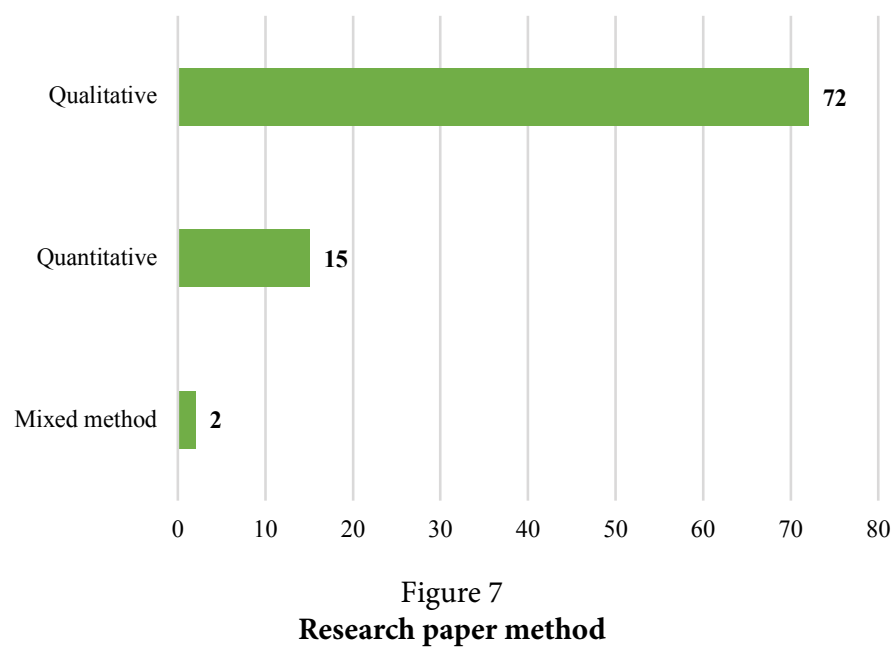

Source: Own elaboration from WoS.

Figure 8 shows the number of articles published in each of the years considered in our sample. It shows the trend is upward. If we pay attention to the first years, the number of publications is quite low. However, since 2018 the publication trend gains strength. That is stronger in 2019. Finally, 2020 the trend is expected to continue growing. This suggests that the interest in the subject is clearly increasing as trend line indicated.

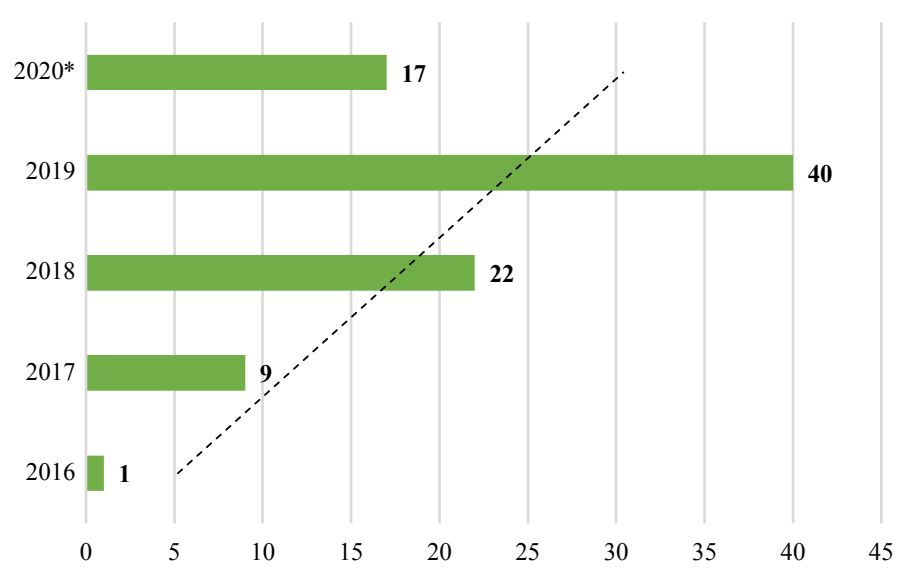

Figure 8

Number of publications (2016-2020)

Source: Own elaboration from WoS.

${ }^{*}$ Boolean search for this research was conducted on June 1, 2020.

Regarding the aggregated data by continent, research based on European data accounts nearly half of the total (42.69\%). Nearby are the international studies (41.57\%). Asia (12.36\%) follows. In the queue are America (2.24\%) and Africa (1.12\%).

Specifically, $35.96 \%$ of the studies carried out at country level $(\mathrm{n}=32)$, are based on samples from the China (5.62\%) rank first. Sweden at par Romania (4.49\%), rank second. United Kingdom, Spain and India (3.37\%) rank third. Figure 9 illustrates these results.

Finally, the five most important sample papers in terms of citations were analysed. Their main features are listed in Table 2.

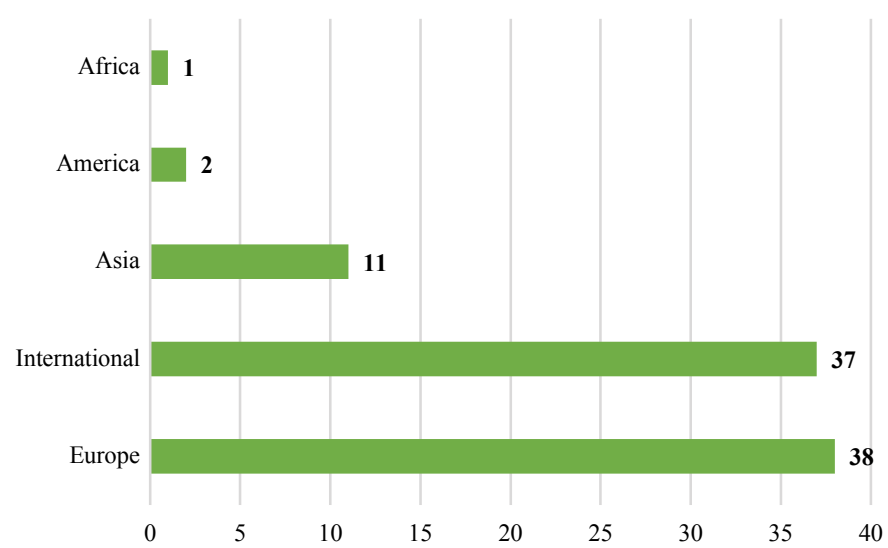

Figure 9

Geographical scope

Source: Own elaboration from WoS.

Table 2

The most cited articles on the circular economy

\begin{tabular}{lcll}
\hline \multicolumn{1}{c}{ Citation } & $\begin{array}{c}\text { No. of } \\
\text { citations }\end{array}$ & $\begin{array}{c}\text { Research } \\
\text { method }\end{array}$ & $\begin{array}{c}\text { Further } \\
\text { information }\end{array}$ \\
\hline Murray et al., 2017 & 1505 & Qualitative & CE origins \\
Genovese et al., 2017 & 707 & Qualitative & Process industries \\
Linder and Williander, 2017 & 499 & Qualitative & Manufacturing \\
Despeisse et al., 2017 & 225 & Quantitative & 3D printing \\
Todeschini et al., 2017 & 222 & Qualitative & Fashion industry \\
\hline
\end{tabular}

Source: Own elaboration from WoS.

\section{RESULTS}

To achieve a better understanding of the findings of this systematic review, the arguments are organised in sections (Figure 10). The first one groups the main antecedents, which include sustainability and circular business models, recycling, industrial symbiosis, and remanufacturing. The second presents CE in general terms and its possible drivers and challenges. It can be seen that it is an interdisciplinary field. This section is structured in three sub-sections: small and medium-sized enterprises, the textile industry, and the food sector. The third section suggests some of the possible effects of the CE. According to the data obtained, they include ecological innovations, supply chain management, and artificial intelligence. The final section places the $\mathrm{CE}$ in a global context.

\subsection{Antecedents}

\section{Sustainability and Circular Business Models}

Industry has long been asking for guidance in implementing sustainable development strategies. The CE represents the most recent attempt to conceptualise the sustainable integration of economic activity and environmental well-being (Murray et al., 2017). This is because the linear economy production model and mass consumption are testing the limits and resources of the planet; they have made the present system unsustainable, and thus in urgent need of a new approach (Esposito et al., 2018). 


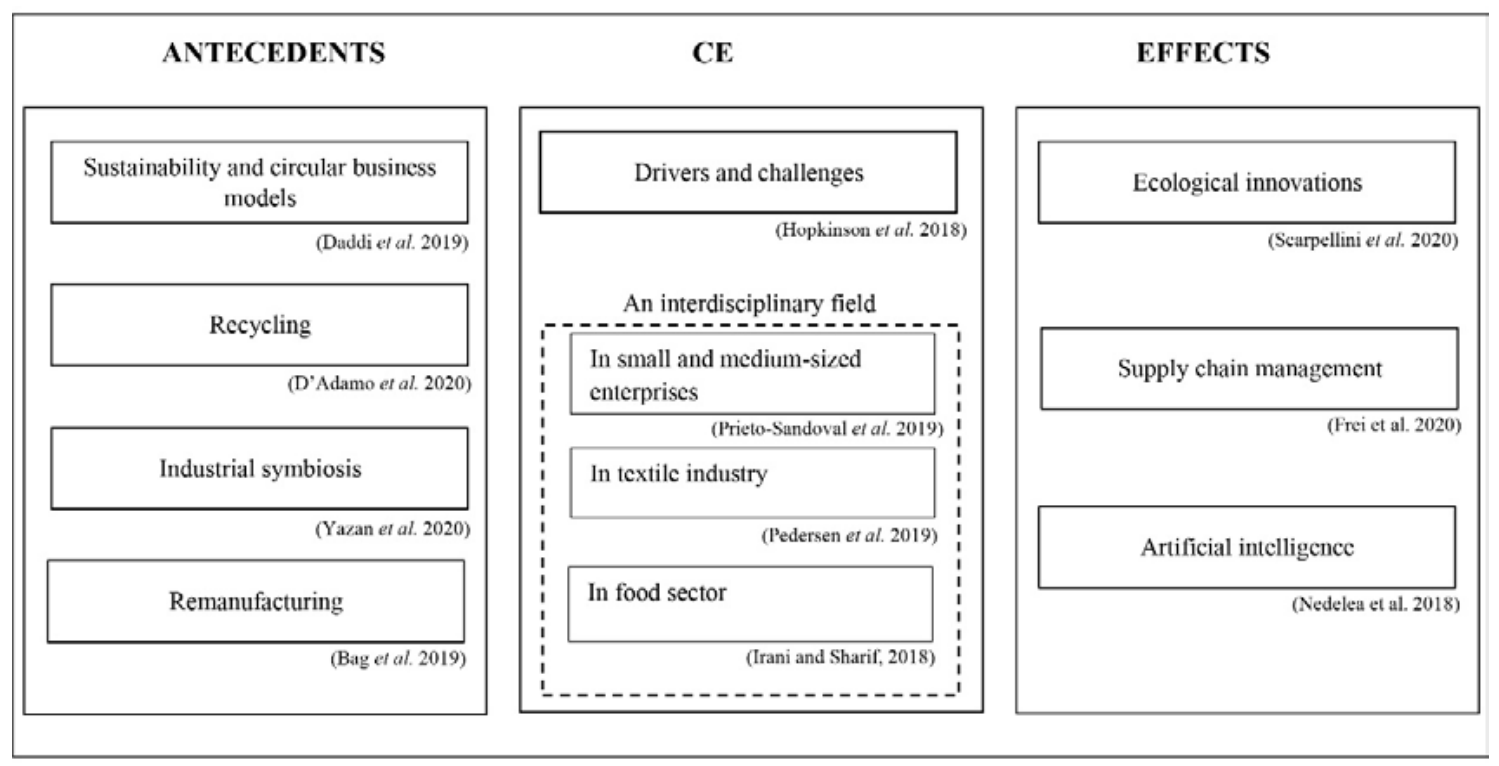

Figure 10

Circular economy research

Source: Own elaboration from WoS.

Sustainability is of great interest to the business sector. This is demonstrated by the fact that more than 13,000 companies in 160 countries have signed the United Nations Global Compact (Lozano, 2020). The CE is increasingly seen as a way for organisations and national economies to become environmentally sustainable (Brown and Bajada, 2018). The CE cannot be understood without sustainability (Dubey et al., 2019), environmental protection policies are crucial for its future development (Cainelli et al., 2020). The CE pushes the boundaries in its emphasis on the idea of transforming products so that the relationship between ecological systems and economic growth can be made more viable. It therefore concerns not just in limiting the use of the environment as a sink, but also with creating self-sustaining production systems in which materials are continuously reused (Genovese et al., 2017).

Specifically, industrial sustainability advocates the grand vision of a generative, restorative, and positive economy (Smart et al., 2017). Circular business models are receiving increasing attention in academia and business (Chen et al., 2020). To this end, measurements are made of the profitability of the implementation of these models. Ionascu and Ionascu (2018) explain that the adoption of a sustainable business model does not penalise companies economically, but rather serves to boost their performance. To control the level of sustainability of an industry, so-called sustainability reports are also widely used. They have recently begun to be used in air transport (Karagiannis et al., 2019).

Occasionally, actions that promote sustainability lead to unwanted environmental consequences (Laurenti et al., 2016). This may be the result of their own company's ecosystem. In other words, the complexity and interdependencies of enterprises mean that no single company can make the transition to a $\mathrm{CE}$ on its own; the entire ecosystem must be adjusted (Parida et al., 2019). Another challenge that companies face when promoting sustainability is paradoxical tension, that is, the risk they are exposed to when they carrying out actions that favour the environment, but which can result in a decrease in quality and competitiveness. Defensive and proactive strategies must be adopted to manage such a situation (Daddi et al., 2019).

\section{Recycling: The Starting Point of the Circular Economy}

Recycling is key to the realisation of $\mathrm{CE}$ and sustainable development (Pelau and Chinie, 2018). An economic system based on business models that replace the end-of-life concept in production processes with the objective of achieving sustainable development implies the creation of a clean environment (Kębłowski et al., 2020), economic prosperity, and social equality for the benefit of current or future generations (Dey et al., 2020). One of the variables that can influence recycling is the educational level of the population. Studies have shown that higher education has a positive influence on the extent to which products are recycled (Pelau and Chinie, 2018). Another variable is internal conflicts and cooperation during manufacturing (Wu et al., 2017).

D'Adamo et al. (2020) conducted a study on the evaluation of the possible correlation between end-of-life vehicle flows and GDP and population variables. They concluded that an increase in GDP translates into a greater quantity of recycled vehicles at the end of their useful life, showing a synergy between the $\mathrm{CE}$ and technology (D’Adamo et al., 2020).

Finally, the latest trends in recycling, through the emerging technologies of Industry 4.0, are integrated with CE practices to establish a business model that reuses and recycles waste material, such as electronic waste. Business sustainability benefits when waste is reintroduced into the supply chain for manufacture products (Nascimento et al., 2019). However, recycling should be considered as complementary to $\mathrm{CE}$. The use of renewable 
energy is equally important for the achievement of a healthy and sustainable ecosystem (Andronie et al., 2019).

\section{Industrial Symbiosis: The Importance of COOPERATION INSTEAD OF COMPETITIVENESS}

From the strategic point of view, the objective of every company is to obtain a sustainable and lasting competitive advantage over time, which is why the CE is used as part of competitiveness strategy.

Yazan et al. (2020) and Sehnem (2019) analyse the benefits and impacts of the CE using very new concepts, such as industrial symbiosis. The latter is vitally important for companies if they are to implement $\mathrm{CE}$ systems cooperatively rather than competitively.

Collaboration between companies is fundamental in cooperative strategic behaviour. It is not easily achievable. To solve the problems created by competition, Yazan et al. (2020) propose a theoretical model of non-cooperative games to share additional costs. This involves two strategies - fair vs. opportunistic. The latter brings more benefits in the short term, while the former more appropriate over the long term (Yazan et al., 2020).

\section{Remanufacturing as a Tool to Implement the Circular ECONOMY}

One way of applying the $\mathrm{CE}$ is through remanufacturing. This allows for sustainable manufacturing because the residual value is reused in old products. The costs of material inputs, energy, and the extension of the product life cycle are reduced. Dynamic remanufacturing capability refers to the ability to optimise and apply variation in production lines by altering the processing times of individual components. This requires first, systems of flexibility that permit modifications according to the volume of products recovered and the requests of the end customers; and, second, control systems that enable the supervision of operations in a cost effective way to reduce the associated risks (Bag et al., 2019).

Shao et al. (2019) highlight the contributions of remanufacturing to sustainable development and the CE. A company's decision to adopt this strategy is fraught with uncertainty, especially when it involves a major capital investment (Low and Ng, 2018). Consumers must also participate; for the CE to be sustainable, they must not only return the products after use, but also buy the products that have been remanufactured (Hazen et al., 2017).

Kalverkamp (2018) considered remanufacturing in relation to the circular flow of products using used components or reverse logistics in the automotive industry. The main obstacles to the use of used components are correct identification, the probability that they are illegal, and the large number of suppliers. Electronic procurement is suggested as a remedy, because this can improve component availability, save time, lower transaction costs, and make remanufacturers more competitive. The potential for improved relationships with suppliers in the circular supply chain is also apparent (Kalverkamp, 2018; Kalverkamp and Raabe, 2018). Government and economic stability, environmental sustainability, and the availability of raw materials all impact the remanufacturing sector (Mishra et al., 2019).

\subsection{The Circular Economy}

\subsubsection{Drivers and Challenges}

Table 3 displays the main drivers of and barriers to the CE, as outlined by authors such as Hopkinson et al. (2018), Frishammar and Parida (2019), Sehnem et al. (2019), Jaeger and Upadhyay (2020), Agyemang et al. (2019), and Vimal et al. (2019).

Table 3

Summary of the main drivers of and barriers to the circular economy

Drivers Barriers

Generation of new income

(Agyemang et al., 2019)

Resource productivity (Frishammar and Parida, 2019)

(Hopkinson et al., 2018)

Social legitimacy

(Agyemang et al., 2019)

Raw material savings

(Hopkinson et al., 2018)

Ability to cope with competitors (Agyemang et al., 2019)

Adoption of new policies and legislation

(Hopkinson et al., 2018)

Source: Own elaboration.

Companies have an obligation to meet these challenges. One way to do this is by creating business cultures that embrace the EC, socio-ecological innovation, and a vision of excellence that incorporates resilience, strength, and sustainability (Edgeman, 2020).

\subsubsection{The Circular Economy: An Interdisciplinary Field}

The CE is advancing rapidly. One of the basic aims behind it is to delay the end of the product's life, and that outputs become inputs for other production cycles (Vuţă et al., 2018). This also means that new sources of income can be tapped. The reconceptualisation of waste as a resource means adopting new innovative strategies for existing supply chains (Perey, 2018).

The CE can be applied to all sectors. First, it has a place in the development of new products Pinheiro et al. (2019). Bundgaard and Huulgaard (2019) have investigated whether it has relevance for luxury items. They show that there are links between some of the basic characteristics of luxury products and the CE. These include high quality and durability (which make products less disposable).

It now plays a key role in the service industry, and in particular hotels (Pamfilie et al., 2018). Jones and Wynn (2019) note that at present, the level of theoretical understanding does not lend itself to management strategies. They suggest that information systems could be better deployed to apply the concepts of the CE. 
Finally, three-dimensional printing offers great potential for developing local material recycling and manufacturing cycles, and environmentally sustainable manufacturing in general (Unruh, 2018), by enabling designs that extend the life of products (Kunz et al., 2018) in a way that takes advantage of economies of scope rather than of scale (Despeisse et al., 2017). However, in addition to the obstacles commonly associated with the development of the CE, the low quality of products in the sector means that further technological innovation is needed. A detailed analysis of the three CE fields is given below.

\section{In Small and Medium-Sized Enterprises (SMEs)}

Globally, SMEs represent $90 \%$ of companies. They are responsible for $60-70 \%$ of employment and more than $70 \%$ of industrial pollution. They are therefore key actors in the implementation of the CE concept (Prieto-Sandoval et al., 2019). The CE has become an important issue in recent years because it makes sustainable development viable in terms of value creation (Prieto-Sandoval et al., 2018). However, research linking CE practices to sustainability performance amongst SMEs is scarce (Dey et al., 2020).

Achieving sustainability in SMEs is necessary if social and environmental challenges are to be met, and if such companies are to maintain competitive advantage (Ünal 2019). Prieto-Sandoval et al. (2018) identify the elements that enable SMEs to understand where they are and what they need to do to improve their performance within the CE: fields of action of CE, industrial symbiosis, and environmental certification.

However, SMEs face numerous barriers when attempting to implement CE strategies (García-Quevedo, 2020). The specific characteristics of the four types of SME have to be taken into consideration when practices necessary for the application of the $\mathrm{CE}$ are being implemented (Bassi and Dias, 2020). According to Bassi and Dias (2020), they are: companies with no interest in $\mathrm{CE}$, not adopting or planning to adopt CE practices; companies in the process of introducing CE; companies interested only in specific CE practices; and companies with a very positive attitude towards the green economy that already implement the CE practices analysed.

A novel study by Katz-Gerro and López Sintas (2019) has changed the way most researchers think about the CE. The authors argue that $\mathrm{CE}$ activities are independent of each other. They list those that are most likely to be carried out by SMEs in descending order: waste minimisation; re-planning of energy use; product redesign; and use of renewable energy along /with re-planning of water use.

\section{In THE TeXTILE INDUSTRY}

It is assumed that new textile recycling technologies have the potential to redirect material resource flows, affect global secondary markets, and reconfigure the waste hierarchy (Norris, 2019). Consumers can play a major role in the implementation of the $\mathrm{CE}$, as they are responsible for a company's social legitimacy. This is a direct consequence of a change of mentality on their part. They increasingly value practices that respect society and the environment (Barbu et al., 2018). Companies have to be aware of these different consumer behaviour patterns (Horvath et al., 2019).

In this context, it is appropriate to speak of ecological awareness. Firms can influence the consumption behaviour of their customers, because they are willing to pay more money for sustainable products (Pal, 2019), (Unterfrauner et al., 2019). They demand clearly visible evidence (e.g., on packaging) of the manufacturers' eco-friendliness (Vehmas et al., 2018).

The textile industry in particular merits further attention, because it is one of the most polluting industries in the world (Vehmas et al., 2018), and the exponential growth of garments that end up in landfill is one of the biggest of the CE (Hvass and Pedersen, 2019). This is the result of the phenomenon of fast fashion (i.e., the rapid production and consumption of clothing), which has created the impression that clothes are disposable (Todeschini et al., 2017).

To solve this problem, sustainable fashion capable of developing circular flows of material is necessary (Corvellec et al., 2020). This requires consumers' collaboration in promoting slow fashion, opting for quality over quantity, and regarding garments as an investment (Vehmas et al., 2018). Efficient garment collection systems and sorting procedures are also needed (Pedersen et al., 2019). In conclusion, the application of the CE in fashion involves business model innovation, organisational change, transformation of the value proposition, the creation of new alliances with stakeholders, and customer engagement.

\section{IN THE FoOd SECTOR}

Another area in which the CE has developed recently is the food sector, which has adopted circular business models (Zucchella and Previtali, 2019). Adapting to the CE and sustainability is a complex affair. Organisations are therefore lobbying to adopt $\mathrm{CE}$ initiatives that will improve the economic-ecological-social sustainability of supply chains (Sharma et al., 2019). A number of obstacles stand in the way.

First, barriers exist in the supply chains. The cause and effect relationships between them have been identified, so the philosophy of CE can be applied to food supply chain management (Farooque et al., 2019). The two predominant causal barriers are weak environmental regulations and a lack of market pressure.

Second, food security is a challenge. This can be addressed through strategic planning. Irani and Sharif (2018). use PESTLE analysis, but they point out that this tool may not be useful for all enterprises. They suggest that strategic planning tools should be employed to capture the large number of interrelated factors that impact food security.

Third, developing countries face greater obstacles than developed ones. Most of the former lack the necessary infrastructure for sustainable development (Zaidi et al., 2019).

\subsection{Effects}

\section{ECOLOGICAL INNOVATIONS}

The first factor that goes hand in hand with CE, as an effect, is ecological innovations. The assumption is that companies' ecological innovations mitigate damage to the environment 
(Provasnek et al., 2017). Ecological innovations reduce the environmental impact of production and consumption activities. They play a fundamental role in achieving more sustainable societies because they transfer individual technologies (Scarpellini et al., 2020). Green innovations need even more cooperation between stakeholders, because they require more external sources of knowledge and information than innovation in general (Kiefer et al., 2019). Rajala et al. (2018), argue that, despite the existence of a perfect recyclable material, for the $\mathrm{CE}$ to flourish there must be an ecosystem in place that is built for cooperative recycling.

A recent study identifies two main avenues for ecological innovations: cleaner production and green product design. The authors point out that the positive impact of innovations on companies is conditioned by their structure, characteristics, specific innovation strategies, and the industry context (Demirel and Danisman, 2019).

Scarpellini et al. (2020) categorise eco-innovation related to the $\mathrm{CE}$ as: investment in eco-innovation, eco-design, investment and improvement of innovative and renewable equipment or processes for energy efficiency, and investment in R\&D. The authors suggest that the impact of informal environmental management tools, in contrast with formal ones, go beyond the level of circular ecological innovation to affect the circular activity of the company, thus helping to strengthen the circular material circuit (Scarpellini et al., 2020).

Finally, Jakhar et al. (2019) explain why different companies under similar stakeholder pressures adopt different circular practices. The determinant is their capacity for innovation. There are two forms: exploratory, where companies are synchronised for rapid change and are able to achieve sustainable competitive advantage; and exploitative, where they are opposed to circular needs. The authors conclude that stakeholders negatively influence innovative, exploitative-type capabilities in the absence of incentives to integrate into the CE.

\section{Supply Chain Management in the Circular Economy}

Although the CE has the power to achieve business sustainability, most companies are unable to incorporate it into their strategies, business models, and operations (Stewart and Niero, 2018; Agrawal et al., 2019).

Khan et al. (2020) confirm that companies that have tried to do so have been able to identify and respond to circular opportunities successfully. Specifically, they employed the life-cycle assessment of objects, as well as the development of green products and sustainable innovations, and achieved industrial symbiosis.

Another pillar of the $\mathrm{CE}$ is green supply chain management (GSCM). This can create value for companies and society as a whole. It has even influenced public policy (Tang, 2018). Frei, Jack and Krzyzaniak (2020) state that sustainability, loss prevention, and profit optimisation go hand in hand with the right approach to reverse supply chain organisation (Frei et al., 2020). The alignment of GSCM and the CE has certainly benefited some organisations. The emphasis in GSCM tends to be on environmental performance, and in the CE on economic performance (Liu et al., 2018; Ripanti and Tjahjono, 2019). Al- though GSCM in emerging markets is an area of research with great potential (Tang, 2018), most studies have been conducted in developed countries.

\section{Artificial Intelligence And the Circular Economy}

The third factor that goes hand in hand with $\mathrm{CE}$, as a benefit of it, is artificial intelligence.

Nedelea et al. (2018) suggest that companies use their innovation, management, and intellectual capital to acquire competitive advantage, but human capital in general is central. Employees can be motivated and trained in the context of a CE-oriented organisational culture.

Also, Artificial Intelligence (AI) has much to off the CE. It can provide tools capable of optimising industrial processes and predicting possible behaviours that help to control the waste generated. These have improved exponentially in recent years. It is vital that AI systems capable of resolving complex challenges, and which are based on big data analysis and machine learning, are nurtured (Sriram, 2006).

\subsection{The Circular Economy in a Global Context}

The concept of CE has become increasingly important in European Union (EU) policy making. The EU is one of the territories where measures are being taken to support the implementation of sustainable development strategies and the transition from the linear economy to the CE (Völker, 2020).

More studies on remanufacturing business models in China - a CE pioneer - are needed (Shao, 2019). Zhu et al. (2019) examination of the economic viability and entrepreneurial spirit of circular businesses in China demonstrates that a circular approach can help achieve ecological, economic, and social objectives in emerging economies, though entrepreneurship is fundamental to all of them (Zhu et al., 2019).

\section{CONCLUSIONS}

The purpose behind identifying and systematising journal articles on the CE and sustainability was to discover aspects of the topic that remain unexplored, or that could be studied more in depth. It adds to existing knowledge by providing a systematic synthesis of research on the subject and pointing out shortfalls in the literature. Thus, this paper contributes to the existing literature by providing a systematic review of sustainability and $\mathrm{CE}$, generating a theoretical foundation for further empirical work.

The CE has been presented as the solution to the world's environmental crisis. The adoption and application of this business management paradigm is, however, a challenge (Gupta et al., 2019). More studies on how the CE can be implemented effectively are needed, but it is important that it be investigated in terms of sustainability, innovation, and entrepreneurship. That said, as a sub-discipline, CE research is still in its infancy.

The path towards the achievement of Goal 12 (one of the United Nations' SDGs) still requires changes in the current mode of production and consumption. Therefore, we must continue to 
invest in sustainability and circular production models, so that the $\mathrm{CE}$ becomes the economic paradigm at a global level.

\subsection{Managerial implications}

There is a need to implement CE throughout the business ecosystem. However, as Table 3 shows, this is not a straightforward task. It is recommended that company managers do the following: invest in human capital to acquire the skills and abilities that they need; invest in research, development, and innovation $(\mathrm{R}+\mathrm{D}+\mathrm{i})$ to design programmes capable of promoting the implementation of CE and of replacing linear systems with circular ones; purchase installations and machinery that can be integrated into the CE; and make additional investments in research that will provide them with information on the most efficient ways to do all the above. Although large capital investment will be needed, it will yield high profits in the long term.

\subsection{Limitations and future research}

First, the study's qualitative approach produced subjective results that might have been supported by more empirical evidence. Second, a single methodology (a systematic review of the literature) was employed and also it excludes SCI journals with a multidisciplinary approach to environmental management and sustainability; other techniques could be adopted in future research. A third limitation was that only one database was consulted. This issue could also be addressed in later studies.

In future work on the CE, time series data could be used, and developing countries analysed. The impact of trade dynamics, secondary raw materials, and recycling on different macroeconomic variables could also be investigated.

Finally, this systematic review has revealed how the study of $\mathrm{CE}$ and sustainability is a promising research field. More deeply, other implications that derive from our review suggest that there are significant research gaps that may be subject of attention in the future research agenda.

By one hand, the focus should be on social actors as there are gaps in the literature on these actors. Thus, CE should be approached from the perspective of business, government and households. Since the generation of efficient CE and sustainability systems represent the main interests to organisations and society. The development and implementation of integrated CE and sustainability systems could boost business competitiveness, generate more employment, improve social welfare, and adapt regulatory frameworks to create strategic synergies.

By other hand, digital transformation can change the future dynamics of CE and sustainability. The creation of digital systems that allow the integration of large volumes of data, as well as the implementation of mechanisms that manage circular business models, represents a promising field of research. It is important to efficiently manage circularity processes, but without an adequate security and protection system, the availability of valuable knowledge sources does not guarantee the achievement of competitive advantages. Therefore, analysing the determinants, effects and consequences of the implementation of automatic $\mathrm{CE}$ process safety systems may be another enriching line of research in future studies.

\section{ACKNOWLEDGEMENTS}

We acknowledge financial support from the Spanish Ministry of Economy and Competitiveness and FEDER (project ECO2017-85451-R), and from the Spanish Ministry of Science, Innovation and Universities (SIA: 998758 2019).

\section{REFERENCES}

Agrawal, V. V., Atasu, Atalay., \& Van Wassenhovec (2019). New Opportunities for Operations Management Research in Sustainability. $M \backslash \mho S o m-M a n u f a c t u r i n g ~ \& ~ S e r v i c e ~ O p e r a t i o n s ~ M a n a g e m e n t, 21(1)$, 1-12. DOI: $10.1287 / \mathrm{msom} .2017 .0699$

Agyemang, M., Kusi-Sarpong, S., Khan, S., Mani, V., Rehman, S., \& Kusi-Sarpong, H. (2019). Drivers and barriers to circular economy implementation: An explorative study in Pakistan's automobile industry. Management Decision, 971-994. DOI: 10.1108/MD-11-2018-1178

Ahmed, B. (2018). Who takes responsibility for the climate refugees? International Journal of Climate Change Strategies and Management. DOI: 10.1108/IJCCSM-10-2016-0149

Allwood, J. M., Ashby, M. F., Gutowski, T. G., \& Worrell, E. (2011). Material efficiency: A white paper. Resources, Conservation and Recycling, 55(3), 362-381. DOI: 10.1016/j.resconrec.2010.11.002

Andronie, M., Simion, V., Gurgu, E., Dijmărescu, A., \& Dijmărescu, I. (2019). Social responsibility of firms and the impact of bio-economy in intelligent use of renewable energy sources. The Amfiteatru Economic journal, 21(52), 520-520. DOI: 10.24818/ea/2019/52/520

Bag, S., Gupta, S., \& Foropon, C. (2019). Examining the role of dynamic remanufacturing capability on supply chain resilience in circular economy. Management Decision, 57(4), 840-862. DOI: 10.1108/ MD-07-2018-0724

Barbu, C. M., Florea, D. L., Ogarcă, R. F., \& Barbu, M. C. (2018). From Ownership to access: How the sharing economy is changing the consumer behavior. Amfiteatru Economic, 20(48), 373-387. DOI: $10.24818 / \mathrm{ea} / 2018 / 48 / 373$

Bassi, F., \& Dias, J. G. (2020). Sustainable development of small-and medium-sized enterprises in the European Union: A taxonomy of circular economy practices. Business Strategy and the Environment, 29(6), 2528-2541. DOI: 10.1002/bse.2518

Brown, P. J., \& Bajada, C. (2018). An economic model of circular supply network dynamics: Toward an understanding of performance measurement in the context of multiple stakeholders. Business Strategy and the Environment, 27(5), 643-655. DOI: 10.1002/bse.2069

Bundgaard, A. M., \& Huulgaard, R. D. (2019). Luxury products for the circular economy? A case study of Bang \& Olufsen. Business Strategy and the Environment, 28(5), 699-709. DOI: 10.1002/bse.2274

Cainelli, G., D’Amato, A., \& Mazzanti, M. (2020). Resource efficient eco-innovations for a circular economy: Evidence from EU firms. Research Policy, 49(1). DOI: 10.1016/j.respol.2019.103827

Centobelli, P., Cerchione, R., Chiaroni, D., Del Vecchio, P., \& Urbinati, A. (2020). Designing business models in circular economy: A systematic literature review and research agenda. Business Strategy and the Environment, 29(4), 1734-1749. DOI: 10.1002/bse.2466

Chen, L. H., Hung, P., \& Ma, H. W. (2020). Integrating circular business models and development tools in the circular economy transition process: A firm-level framework. Business Strategy and the Environment, 29(5), 1887-1898. DOI: 10.1002/bse.2477

Corvellec, H., \& Stål, H. I. (2019). Qualification as corporate activism: How Swedish apparel retailers attach circular fashion qualities to take-back systems. Scandinavian Journal of Management, 35(3), 101046. DOI: 10.1016/j.scaman.2019.03.002 
Corvellec, H., Böhm, S., Stowell, A., \& Valenzuela, F. (2020). Introduction to the special issue on the contested realities of the circular economy. Culture and Organization, 26(2), 97-102. DOI: 10.1080/14759551.2020.1717733

D’Adamo, I., Gastaldi, M., \& Rosa, P. (2020). Recycling of end-of-life vehicles: Assessing trends and performances in Europe. Technological Forecasting and Social Change, 152, 119887. DOI: 10.1016/j. techfore.2019.119887

Daddi, T., Ceglia, D., Bianchi, G., \& Barcellos, M. (2019). Paradoxical tensions and corporate sustainability: A focus on circular economy business cases. Corporate Social Responsibility and Environmental Management, 26(4), 770-780. DOI: 10.1002/csr.1719

Demirel, P., \& Danisman, G. O. (2019). Eco-innovation and firm growth in the circular economy: Evidence from European small-and medium-sized enterprises. Business Strategy and the Environment, 28(8), 1608-1618. DOI: 10.1002/bse.2336

Despeisse, M., Baumers, M., Brown, P., Charnley, F., Ford, S. J., Garmulewicz, A., \& Rowley, J. (2017). Unlocking value for a circular economy through 3D printing: A research agenda. Technological Forecasting and Social Change, 115, 75-84. DOI: 10.1016/j.techfore.2016.09.021

Dey, P. K., Malesios, C., De, D., Budhwar, P., Chowdhury, S., \& Cheffi, W. (2020). Circular economy to enhance sustainability of small and medium-sized enterprises. Business Strategy and the Environment, 29(6), 2145-2169. DOI: 10.1002/bse.2492

Dubey, R., Gunasekaran, A., Childe, S., \& Papadopoulos, T. (2019). Supplier relationship management for circular economy: Influence of external pressures and top management commitment. Management Decision, 57(4), 767-790. DOI: 10.1108/MD-04-2018-0396

Edgeman, R. (2020). Urgent evolution: excellence and wicked Anthropocene Age challenges. Total Quality Management \& Business Excellence, 31(5-6), 469-482. DOI: 10.1080/14783363.2018.1430510

Ellen MacArthur Foundation [EMAF] (2015). Growth Within: A Circular Economy Vision for a Competitive Europe, Retrieved from https://www.ellenmacarthurfoundation.org/assets/downloads/publications/EllenMacArthurFoundation_Growth-Within_July15.pdf

Esposito, M., Tse, T., \& Soufani, K. (2018). Introducing a circular economy: new thinking with new managerial and policy implications. California Management Review, 60(3), 5-19. DOI: 10.1177/0008125618764691

European Commission. (2016). EUR-Lex. Directiva Marco de Residuos. Retrieved from https://eur-lex.europa.eu/legal-content/ES/TX$\mathrm{T} /$ ? uri=LEGISSUM\%3Aev0010

European Commission. (2018). Report on Critical Raw Materials and the Circular Economy. Register of Commission Documents $S W D(2018) 36$. Retrieved from https://ec.europa.eu/transparency/ documents-register/detail?ref=SWD(2018)36\&lang=en

European Commission. (2021). Circular Economy - Overview. Retrieved from https://ec.europa.eu/eurostat/web/circular-economy/overview

Farooque, M., Zhang, A., \& Liu, Y. (2019). Barriers to circular food supply chains in China. Supply Chain Management: An International Journal, 24(5), 677-69. DOI: 10.1108/SCM-10-2018-0345

Frei, R., Jack, L., \& Krzyzaniak, S. A. (2020). Sustainable reverse supply chains and circular economy in multichannel retail returns. Business Strategy and the Environment, 29(5), 1925-1940. DOI: 10.1002/ bse. 2479

Frishammar, J., \& Parida, V. (2019). Circular business model transformation: A roadmap for incumbent firms. California Management Review, 61(2), 5-29. DOI: 10.1177/0008125618811926

García-Quevedo, J., Jové-Llopis, E., \& Martínez-Ros, E. (2020). Barriers to the circular economy in European small and medium-sized firms. Business Strategy and the Environment, 29(6), 2450-2464. DOI: $10.1002 /$ bse. 2513

Gao, L., Melero, I., \& Sese, F. J. (2020). Multichannel integration along the customer journey: a systematic review and research agen- da. The Service Industries Journal, 40(15-16), 1087-1118. DOI: 10.1080/02642069.2019.1652600

Geissdoerfer, M., Savaget, P., Bocken, N.M., Hultink, E.J. (2017). The Circular Economy- A new sustainability paradigm? Journal of Cleaner Production, 143, 757-768. DOI: 10.1016/j.jclepro.2016.12.048

Genovese, A., Acquaye, A. A., Figueroa, A., \& Koh, S. L. (2017). Sustainable supply chain management and the transition towards a circular economy: Evidence and some applications. Omega, 66(B), 344-357. DOI: 10.1016/j.omega.2015.05.015

Ghisellini, P., Cialani, C., Ulgiati, S. (2016). A review on circular economy: the expected transition to a balanced interplay of environmental and economic systems. Journal of Cleaner Production, 114, 11-32. DOI: 10.1016/j.jclepro.2015.09.007

Gupta, S., Chen, H., Hazen, B. T., Kaur, S., \& Gonzalez, E. D. (2019). Circular economy and big data analytics: A stakeholder perspective. Technological Forecasting and Social Change, 144, 466-474. DOI: 10.1016/j.techfore.2018.06.030

Hazen, B. T., Mollenkopf, D. A., \& Wang, Y. (2017). Remanufacturing for the circular economy: An examination of consumer switching behavior. Business Strategy and the Environment, 26(4), 451-464. DOI: 10.1002/bse.1929

Hopkinson, P., Zils, M., Hawkins, P., \& Roper, S. (2018). Managing a complex global circular economy business model: opportunities and challenges. California Management Review, 60(3), 71-94. DOI: $10.1177 / 0008125618764692$

Horvath, B., Khazami, N., Ymeri, P., \& Fogarassy, C. (2019). Investigating the current business model innovation trends in the biotechnology industry. Journal of Business Economics and Management, 20(1), 63-85. DOI: 10.3846/jbem.2019.6880

Hvass, K. K., \& Pedersen, E. R. (2019). Toward circular economy of fashion: Experiences from a brand's product take-back initiative. Journal of Fashion Marketing and Management, 23(3), 345-365. DOI: 10.1108/JFMM-04-2018-0059

Ionascu, I., \& Ionascu, M. (2018). Business models for circular economy and sustainable development: The case of lease transactions. Amfiteatru Economic, 20(48), 356-372. DOI: 10.24818/ea/2018/48/356

Irani, Z., \& Sharif, A. M. (2018). Food security across the enterprise: a puzzle, problem or mess for a circular economy? Journal of Enterprise Information Management, 31(1), 2-9. DOI: 10.1108/JEIM-03-2017-0045

Jabbour, C. J. (2019). Unlocking the circular economy through new business models based on large-scale data: an integrative framework and research agenda. Technological Forecasting and Social, 144, 546552. DOI: $10.1016 /$ j.techfore.2017.09.010

Jaeger, B., \& Upadhyay, A. (2020). Understanding barriers to circular economy: cases from the manufacturing industry. Journal of Enterprise Information Management. DOI: 10.1108/JEIM-02-2019-0047

Jakhar, S. K., Mangla, S. K., Luthra, S., \& Kusi-Sarpong, S. (2019). When stakeholder pressure drives the circular economy. Management Decision. DOI: 10.1108/MD-09-2018-0990

Jones, P., \& Wynn, M. G. (2019). The circular economy, natural capital and resilience in tourism and hospitality. International Journal of Contemporary Hospitality Management, 31(6), 2544-2563. DOI: 10.1108/IJCHM-05-2018-0370

Kalverkamp, M. (2018). Hidden potentials in open-loop supply chains for remanufacturing. The International Journal of Logistics Management, 29(4), 1125-1146. DOI: 10.1108/IJLM-10-2017-0278

Kalverkamp, M., \& Raabe, T. (2018). Automotive remanufacturing in the circular economy in Europe: marketing system challenges. Journal of Macromarketing, 38(1), 112-130. DOI: 10.1177/0276146717739066

Karagiannis, I., Vouros, P., Skouloudis, A., \& Evangelinos (2019). Sustainability reporting, materiality, and accountability assessment in the airport industry. Business Strategy and the Environment, 28(7), 1370-1405. DOI: 10.1002/bse.2321 
Katz-Gerro, T., \& López Sintas, J. (2019). Mapping circular economy activities in the European Union: Patterns of implementation and their correlates in small and medium-sized enterprises. Business Strategy and the Environment, 28(4), 485-496. DOI: 10.1002/bse.2259

Kębłowski, W., Lambert, D., \& Bassens, D. (2020). Circular economy and the city: an urban political economy agenda. Culture and Organization, 26(2), 142-158. DOI: 10.1080/14759551.2020.1718148

Khan, O., Daddi, T., \& Iraldo, F. (2020). Microfoundations of dynamic capabilities: Insights from circular economy business cases. Business Strategy and the Environment, 29(3), 1479-1493. DOI: 10.1002/ bse. 2447

Kiefer, C. P., Del Río González, P., \& Carrillo-Hermosilla, J. (2019). Drivers and barriers of eco-innovation types for sustainable transitions: A quantitative perspective. Business Strategy and the Environment, 28(1), 155-172. DOI: 10.1002/bse.2246

Kirchherr, J., Reike, D., \& Hekkert, M. (2017). Conceptualizing the circular economy: An analysis of 114 definitions. Resources, conservation and recycling, 127, 221-232. DOI: 10.1016/j.resconrec.2017.09.005

Korhonen, J., Honkasalo, A., \& Seppälä, J. (2018). Circular economy: the concept and its limitations. Ecological economics, 143, 37-46. DOI: 10.1016/j.ecolecon.2017.06.041

Kunz, N., Mayers, K., \& Van Wassenhove, L. N. (2018). Stakeholder views on extended producer responsibility and the circular economy. California Management Review, 60(3), 45-70. DOI: 10.1177/0008125617752694

Laurenti, R., Singh, J., Sinha, R., Potting, J., \& Frostell, B. (2016). Unintended environmental consequences of improvement actions: a qualitative analysis of systems' structure and behavior. Systems research and behavioral science, 33(3), 381-399. DOI: 10.1002/sres.2330

Linder, M., \& Williander, M. (2017). Circular business model innovation: inherent uncertainties. Business strategy and the environment, 26(2), 182-196. DOI: 10.1002/bse.1906

Liu, J., Feng, Y., Zhu, Q., \& Sarkis, J. (2018). Green supply chain management and the circular economy. International Journal of Phy sical Distribution \& Logistics Management, 48(8), 794-817. DOI: 10.1108/IJPDLM-01-2017-0049

Low, J. S., \& Ng, Y. T. (2018). Improving the economic performance of remanufacturing systems through flexible design strategies: a case study based on remanufacturing laptop computers for the cambodian market. Business Strategy and the Environment, 27(4), 503-527. DOI: $10.1002 /$ bse.2017

Lozano, R. (2020). Analysing the use of tools, initiatives, and approaches to promote sustainability in corporations. Corporate Social Responsibility and Environmental Management, 27(2), 982-998. DOI: 10.1002/csr.1860

Malinauskaite, J., Jouhara, H., Czajczyńska, D., Stanchev, P., Katsou, E., Rostkowski, P., \& Anguilano, L. (2017). Municipal solid waste management and waste-to-energy in the context of a circular economy and energy recycling in Europe. Energy, 141, 2013-2044. DOI: 10.1016/j.energy.2017.11.128

Mishra, S., Singh, S., Johansen, J., Cheng, Y., \& Farooq, S. (2019). Evaluating indicators for international manufacturing network under circular economy. Management Decision, 57(4), 811-839. DOI: 10.1108/MD-05-2018-0565

Murray, A., Skene, K., \& Haynes, K. (2017). The circular economy: an interdisciplinary exploration of the concept and application in a global context. Journal of business ethics, 140(3), 369-380. DOI: 10.1007/s10551-015-2693-2

Nascimento, D., Alencastro, V., Quelhas, O., Caiado, R., Garza-Reyes, J., \& Rocha-Lona, L. (2019). Exploring Industry 4.0 technologies to enable circular economy practices in a manufacturing context. Journal of Manufacturing Technology Management, 30(3), 607-627. DOI: 10.1108/JMTM-03-2018-0071
Nedelea, A. M., Huian, M. C., Bîrsan, M., \& Bedrule-Grigoruță, M. V. (2018). Modeled interdependencies between intellectual capital, circular economy and economic growth in the context of bioeconomy. Amfiteatru Economic, 20(49), 616-630. DOI: 10.24818/ ea/2018/49/616

Norris, L. (2019). Urban prototypes: Growing local circular cloth economies. Business History, 61(1), 205-224. DOI: 10.1080/00076791.2017.1389902

Pajunen, N., \& Heiskanen, K. (2012). Drivers and Barriers in The Supply Chain-The Importance of Understanding The Complexity of Recycling in The Industrial System. In Xxvi International Mineral Processing Congress (Impc) 2012 Proceedings/New Delhi, India/24-28 September 2012., 04047-04056.

Pal, R. S. (2019). Circular fashion supply chain management: exploring impediments and prescribing future research agenda. Journal of Fashion Marketing and Management: An International Journal, 23(3), 298-307. DOI: 10.1108/JFMM-07-2019-166

Pamfilie, R., Firoiu, D., Croitoru, A. G., \& Ionescu, G. H. (2018). Circular Economy-A New Direction for the Sustainability of the Hotel Industry in Romania? Amfiteatru Economic, 20(48), 388-404. DOI: $10.24818 / \mathrm{ea} / 2018 / 48 / 388$

Parida, V., Burström, T., Visnjic, I., \& Wincent, J. (2019). Orchestrating industrial ecosystem in circular economy: A two-stage transformation model for large manufacturing companies. Journal of Business Research, 101, 715-725. DOI: 10.1016/j.jbusres.2019.01.006

Parida, V., \& Wincent, J. (2019). Why and how to compete through sustainability: a review and outline of trends influencing firm and network-level transformation. International Entrepreneurship and Management Journal, 15(1), 1-19. DOI: 10.1007/s11365-019-00558-9

Pedersen, E., Earley, R., \& Andersen, K. (2019). From singular to plural: exploring organisational complexities and circular business model design. Journal of Fashion Marketing and Management: An International Journal, 23(3), 308-326. DOI: 10.1108/JFMM-04-2018-0062

Pelau, C., \& Chinie, A. C. (2018). Econometric model for measuring the impact of the education level of the population on the recycling rate in a circular economy. Amfiteatru Economic, 20(48), 340-355. DOI: $10.24818 / \mathrm{ea} / 2018 / 48 / 340$

Perey, R. B. (2018). The place of waste: Changing business value for the circular economy. Business Strategy and the Environment, 27(5), 631-642. DOI: 10.1002/bse.2068

Pinheiro, M., Seles, B., Fiorini, P., Jugend, D., de Sousa Jabbour, A., da Silva, H., \& Latan, H. (2019). The role of new product development in underpinning the circular economy. Management Decision, 57(4), 840-862. DOI: 10.1108/MD-07-2018-0782

Prieto-Sandoval, V., Jaca, C., Santos, J., Baumgartner, R. J., \& Ormazabal, M. (2019). Key strategies, resources, and capabilities for implementing circular economy in industrial small and medium enterprises. Corporate Social Responsibility and Environment, 26(6), 1473-1484. DOI: $10.1002 / \mathrm{csr} .1761$

Prieto-Sandoval, V., Ormazabal, M., Jaca, C., \& Viles, E. (2018). Key elements in assessing circular economy implementation in small and medium-sized enterprises. Business Strategy and the Environment, 27(8), 1525-1534. DOI: 10.1002/bse.2210

Provasnek, A. K., Sentic, A., \& Schmid, E. (2017). Integrating eco-innovations and stakeholder engagement for sustainable development and a social license to operate. Corporate Social Responsibility and Environmental Management, 24(3), 173-185. DOI: 10.1002/csr.1406

Rajala, R., Hakanen, E., Mattila, J., Seppälä, T., \& Westerlu. (2018). How do intelligent goods shape closed-loop systems? California Management Review, 60(3), 20-44. DOI: 10.1177/0008125618759685

Randers, J. (2012). 2052: A global forecast for the next forty years. Chelsea Green Publishing.

Ripanti, E. F., \& Tjahjono, B. (2019). Unveiling the potentials of circular economy values in logistics and supply chain management. The 
International Journal of Logistics Management, 30(3), 723-742. DOI: 10.1108/IJLM-04-2018-0109

Scarpellini, S., Valero-Gil, J., Moneva, J. M., \& Andreaus, M. (2020) Environmental management capabilities for a "circular eco-innovation”. Business Strategy and the Environment, 29(5), 1850-1864. DOI: $10.1002 /$ bse. 2472

Sehnem, S. C. (2019). Circular business models: level of maturity. Management Decision, 57(4), 1043-1066. DOI: 10.1108/MD-07-20180844

Sehnem, S., Vazquez-Brust, D., Pereira, S., \& Campos, L. (2019). Circular economy: benefits, impacts and overlapping. Supply Chain Management: An International Journal, 24(6), 784-804. DOI: 10.1108/ SCM-06-2018-0213

Shao, J. (2019). Sustainable consumption in China: New trends and research interests. . Business Strategy and the Environment, 28(8), 1507-1517. DOI: 10.1002/bse.2327

Shao, J., Huang, S., Lemus-Aguilar, I., \& Ünal, E. (2019). Circular business models generation for automobile remanufacturing industry in China. Journal of Manufacturing Technology Management, 31(3), 542-571. DOI: 10.1108/JMTM-02-2019-0076

Sharma, Y. K., Mangla, S. K., Patil, P. P., \& Liu, S. (2019). When challenges impede the process For circular economy-driven sustainability practices in food supply chain. Management Decision, 57(4), 9951017.

Smart, P., Hemel, S., Lettice, F., Adams, R., \& Evans, S. (2017). Pre-paradigmatic status of industrial sustainability: a systematic review. International Journal of Operations \& Production Management, 37(10), 1425-1450. DOI: 10.1108/IJOPM-02-2016-0058

Sriram, R. D. (2006). Artificial intelligence in engineering: Personal reflections. Editorial to appear in Advanced Engineering Informatics. DOI: $10.1016 /$ j.aei.2005.12.002

Stewart, R., \& Niero, M. (2018). Circular economy in corporate sustainability strategies: A review of corporate sustainability reports in the fast-moving consumer goods sector. Business Strategy and the Environment, 27(7), 1005-1022. DOI: 10.1002/bse.2048

Tang, C. S. (2018). Socially responsible supply chains in emerging markets: Some research opportunities. Journal of operations management, 57, 1-10. DOI: 10.1016/j.jom.2018.01.002

Todeschini, B. V., Cortimiglia, M. N., Callegaro-de-Menezes, D., \& Ghezzi, A. (2017). Innovative and sustainable business models in the fashion industry: Entrepreneurial drivers, opportunities, and challenges. Business Horizons, 60(6), 759-770. DOI: 10.1016/j.bushor.2017.07.003

Ünal, E. U. (2019). Managerial practices for designing circular economy business models. Journal of Manufacturing Technology Management, 30(3), 561-589. DOI: 10.1108/JMTM-02-2018-0061
United Nations (2015). Sustainable Development Goals. Retrieved from https://www.un.org/sustainabledevelopment/es/objetivos-de-desarrollo-sostenible/. Accessed January 8, 2021

Unruh, G. (2018). Circular economy, 3D printing, and the biosphere rules. California Management Review, 60(3), 95-111. DOI: $10.1177 / 0008125618759684$

Unterfrauner, E., Shao, J., Hofer, M., \& Fabian, C. M. (2019). The environmental value and impact of the Maker movement-Insights from a cross-case analysis of European maker initiatives. Business Strategy and the Environment, 28(8), 1518-1533. DOI: 10.1002/bse.2328

Urbinati, A., Chiaroni, D., \& Chiesa, V. (2017). Towards a new taxonomy of circular economy business models. Journal of Cleaner Production, 168, 487-498. DOI: 10.1016/j.jclepro.2017.09.047

Vehmas, K. R. (2018). Consumer attitudes and communication in circular fashion. Journal of Fashion Marketing and Management: An International Journal, 22(3), 286-300. DOI: 10.1108/JFMM-08-2017-0079

Vimal, K., Rajak, S., \& Kandasamy, J. (2019). Analysis of network design for a circular production system using multi-objective mixed integer linear programming model. Journal of Manufacturing Technology Management, 30(3), 628-646. DOI: 10.1108/JMTM-02-2018-0058

Völker, T. K. (2020). Indicator development as a site of collective imagination? The case of European Commission policies on the circular economy. Culture and Organization, 26(2), 103-120. DOI: $10.1080 / 14759551.2019 .1699092$

Vuţă, M. V. (2018). Assessment of the circular economy's impact in the EU economic growth. Amfiteatru Economic, 20(48), 248-261. DOI: $10.24818 / \mathrm{ea} / 2018 / 48 / 248$

Wu, H., Lv, K., Liang, L., \& Hu, H. (2017). Measuring performance of sustainable manufacturing with recyclable wastes: A case from China's iron and steel industry. Omega, 66(A), 38-47. DOI: 10.1016/j. omega.2016.01.009

Yazan, D., Yazdanpanah, V., \& Fraccascia, L. (2020). Learning strategic cooperative behavior in industrial symbiosis: A game-theoretic approach integrated with agent-based simulation. Business strategy and the environment, 29(5), 2078-2091. DOI: 10.1002/bse.2488

Zaidi, S., Mirza, F., Hou, F., \& Ashraf, R. (2019). Addressing the sustainable development through sustainable procurement: What factors resist the implementation of sustainable procurement in Pakistan? Socio-Economic Planning Sciences, 68(1). DOI: 10.1016/j.seps.2018.11.008

Zhu, Q., Jia, R., \& Lin, X. (2019). Building sustainable circular agriculture in China: economic viability and entrepreneurship. Management Decision, 57(4), 1108-1122. DOI: 10.1108/MD-06-2018-0639

Zucchella, A., \& Previtali, P. (2019). Circular business models for sustainable development: A "waste is food" restorative ecosystem. Business Strategy and the Environment, 28(2), 274-285. DOI: 10.1002/ bse. 2216 